\title{
Factors Used to Determine the Financing Structure for Shareholding Companies Listed in Amman Stock Exchange in Jordan
}

\author{
Raed Kanakriyah ${ }^{1}$ \\ ${ }^{1}$ Accounting Department, Al-Balqa Applied University, Al-Salt, Jordan \\ Correspondence: Dr. Raed Kanakriyah, Accounting Department, Al-Balqa Applied University, Al-Salt 19117, \\ Jordan. Tel: 962-5-3491-111.
}

Received: March 3, 2020

Accepted: May 8, 2020

Online Published: July 8, 2020

doi:10.5430/ijfr.v11n4p462

URL: https://doi.org/10.5430/ijfr.v11n4p462

\begin{abstract}
Purpose - This study aims to explore the main factors that could be used to determine the financing structure for companies listed in Amman Stock Exchange in Jordan. The hypotheses were developed in light of three theories relating financing structure, trade-off theory (TOT), agency theory and pecking order theory (POT).

Design/methodology/approach - The study using unbalanced panel data sample applying regression models for two-dimensions combines cross-sectional and time series for non- financial Jordanian companies listed in ASE over the period 2014-2018. Using standard models include entering a fixed effect, random effect, or not using any effect.

Findings - The findings showed that company size, growth opportunities, and tax-deductible items other than interest have a positive effect on the borrowing, but profitability affects negatively on borrowing. These results are consistent with the arrangement theories (trade-off theory (TOT) and pecking order theory (POT). indicating the factors associated with trade-off theory were stronger than what is usually found in developed countries, and this is an indication of deep problem resulted from asymmetry information in the Jordanian market. which require to focus efforts on how to building the confidence with investors by providing the data that serve them in decision making. This needs to develop the accounting profession which will open the future for an active market for bonds and stocks that serve companies to financing their projects, and not only for speculation.

Practical implications - The results detected how to constitute the suitable financial structure and how making a balance between sources of finance. Also detected weakens role of companies managers and ASE regulators, which require to focusing efforts to improving information deloused to users.

Originality/value - limited number researches which have been discuss this issue. Therefore, this study extensively contributes to the shortage literature on the perceived the main factors that may effect on financial structure.

Research limitations - Availability of financial information plus difficulty accessing information in developing countries such as Jordan.

Keywords: main factors used to determine the financing structure, company size, growth opportunities, and tax-deductible, profitability, trade-off theory (TOT) and pecking order theory (POT), long-term tangible assets, effective tax rate
\end{abstract}

\section{Introduction}

Many theories discuss financial structure and still consider how to determine the suitable financing structure as an important and hot topic in the financial field (Ghose \& Kabra (2019). Taking financial decisions related to the financial structure is considered an important decision that affects competition between companies, so the abilities to obtain funds through debt and to distinguish the cost of debt are central factors in determining the optimal financing structure for companies (Shil, \& Ullah (2019). The financial structure represents the company's ability to use each type of funding source. Companies finance their long-term investments through variety sources of capital. The use of loans is related to the concept of financial leverage, as the loan cost is a fixed financing cost, but it has a lower return required by lenders compared to ownership financing. Also, it achieves tax savings resulting from interest expense. But despite its low cost, it raises the risks that it can be exposed to companies' returns due to cost stability and legal commitment. Thus, the financing structure affects the owners' wealth by affecting the market value of the stock (Fama \& French, 2002; Mekha, et al. 2019). Currently, there is no clear interest in financial structure, and the lack 
interest mainly arises from the absence of adopting scientific methods to determine the appropriate mix of financing structure which assures achieving the company goals. This means determining which structure better finances companies: by debt or equity. As known, Modigliani \& Miller (1958) are considered the first scholars to study the relationship between the company's capital structure and its market value.

The theory of Modigliani \& Miller (1958) states that firm value is not affected by the financing decision. Then, the researchers add the tax effect on the financing decision, because income tax law recognizes loan tax as expense, Thus, it provides tax savings, Therefore, the increase in loans entails a decrease in the funding cost. This means that the market value of the company increases. Therefore, the market value of a borrowing company will be greater than the market value of a non-borrowing company belonging to the same class of risk by looking at the current value of tax savings. The matter did not stop at tax impact. The researchers added several factors that influence the option of a company's financing structure, such as bankruptcy costs, agency costs, and information asymmetry costs. By proposing theories that explain how each of them influence the company financing structure, the researchers found that the financing structure of a company is related to several factors: tangible assets, profitability, company size, and growth opportunities, Researchers have provided explanations for the relationship of these factors to the funding structure based on a theoretical basis.

The main objective of this study is to identify the main factors used to determine the financing structure of Jordanian public shareholding companies (Shil, \& Ullah, 2019). Also, this study will answer the question about the most important factors determining the financing structure, which often depend on limited sources of funding. In an environment such as Jordan's that is characterized by its smallness and its economy being dependent on neighboring countries, the results of this study will constitute additional evidence about the decision to finance in an unstable environment, described with weak economy.

\section{Study Background and Hypothesis Development}

Is there an optimal financing structure that maximizes business value? The first answer to this question was by (Modigliani \& Miller, 1958). They suggest no relationship between the financing structure and the company value, if there is a complete money market, and rational investors, and sufficient information for all, with no taxes or commissions. The researchers concluded that the market value for a company depends only on the ability of its assets to generate cash flows regardless of how these flows are distributed among the financiers. They concluded that the average funding cost for any company is not related to capital structure and exactly equals the cost of equity rights associated with any company that does not use financing (belonging to the same risk category). In 1963, the researchers presented a correction to their theory in the presence of taxes, where they found that the value of the company increases whenever it relies on financing debt as a result of tax interest savings (Shukla, S. 2019). This means that the value of the borrowing company will be higher than the value of the non-borrowing company, and the average cost of funding for a borrowing company will be lower.

But this theory failed to explain why companies do not resort to borrowing in a high way, which is the assumed behavior if borrowing raises the company value. Scholars began looking for a cost component that corresponds to the tax benefits of borrowing and prevents companies from continuing to borrow. So, a group of theories are called differentiation theories. Tradeoff, according to the most important theories, makes a comparison between the benefits of using more debt represented by tax savings and the costs of bankruptcy resulting from additional borrowing (Kraus \& Litzenberger, 1973). This increases dramatically the higher loan volume, and as long as the benefits are higher than the cost, depending on that the company will continue to borrow until the benefits and the cost become equal. Then, the company stops borrowing after that point because the cost of borrowing will be higher than its benefit. The differentiation theories (trade-off theory (TOT) and pecking order theory (POT)) state that there is a balance point, between using debt or equity, which the company must reach to maximize its value. This is called the optimal financing structure (optimal capital structure) (Aggarwal, D \& Padhan, P. 2017).

Another theory is based on differentiation, but between two different types of borrowing benefits and costs, namely the agency's cost of owners' equity and the agency's cost of debts (loans), which is known as the agency theory. A higher debt (loan) percentage in the company requires more monitoring of company management and the decisions it makes, such as investment decision in risky assets, replacement of risky assets in the place of less risky assets or dividends, or increase of salaries. This is because these decisions may affect the degree of risk in the company and its ability to repay debts. For lenders to ensure the commitment of companies' management to the terms of the contracts, they place restrictions on the management's actions of implementing these conditions. Therefore, they bear additional costs called agency costs for debts (loans), which include adding the cost of lower management efficiency as a result of restrictions set by lenders to ensure their rights. Lenders usually work to transfer the agency's cost to 
the owner by raising the interest rate on borrowed money (Jensen \& Meckling 1976). On the other hand, there is an agency cost associated with the use of external financing equity called agency cost of equity. This arises because of the lower ownership of old owners who control the company management, leading to weaken their motivation for work and increasing their motivation to waste, as well as achieving private interests at the expense of the business interest (Jensen \& Meckling, 1976). From here, we see that the option of obtaining financing through debt raises the agency's cost of debt and the option of obtaining equity financing. It increases the agency's cost of equity, and the company has to balance the use of debt and equity financing (capital structure is how to strike a balance between stocks and debt), so that the agency's total cost is kept to a minimum.

The previous theories are based on the assumption of information symmetry between the company's management and external investors (financiers), but management usually has more information (real information) than external investors (Myers \& Majluf, 1984). Through studying the effect of information asymmetry on the financing decision, they found that information asymmetry causes additional costs called costs adverse selection, because of the investor's inability to distinguish between good companies and weak companies. This will not enable the investor to determine the required return. Even if company is as good as its management knows, the investor will not be certain of that. There is always the possibility that the company will be weak. Even the investor's choice may be opposite to what the investor desires. So, investors will require a higher return on investment to compensate for this possibility, which causes the cost of the company's reverse selection. This will make the sources of external financing more expensive. This scenario will lead the company to use internal financing sources as much as possible because it is exposed to the information asymmetry problem.

Also, if the company is forced to resort to external financing, it will resort to financing by debt. This is because issuance of the debt gives a sign (signal) to the investor that the company's management expects a good future, without sharing new shareholders in future, which reduces the costs of reverse selection. Issuance of equity tools gives a negative indication about management expectations, which increases the costs of reverse selection and makes the option to issue ordinary shares as a late option (Myers, 1984; Sakr et al., 2018; Butzbach \& Sarno, 2019). This theory is known as pecking order theory because the company always uses a specific arrangement when selecting funding sources as mentioned. In practical terms, many researchers Shil, \& Ullah, (2019) relied on previous theories in order to determine the factors that influence the decision of the financing structure and the direction of this effect. Practical studies have found that the most important factors affecting the financing decision are size of tangible assets, profitability, company size and growth opportunities (Rajan \& Zingales, 1995) In addition, some studies have found an effect of the effective tax rate and item availability of reduced tax expenses except for interest over the extent of debt dependence (Nenu et al., 2018). Below is a discussion of these determinants.

\subsection{Tangible Assets}

It is known that the assets guarantee the loans. Company long-term tangible assets constitute a guarantee for the lender in the event that the enterprise is exposed to the risk of being unable to repay. This means that the company that has tangible assets is considered less risky and will get loans at lower cost, enabling them to get more financing by debt. This relationship has been interpreted based on the differentiation theory that tangible assets reduce the costs of bankruptcy, while Mekha,et al,. (2019) concludes different result that Earnings per share (EPS), Total Assets and total Revenue (TR) don't have any significant influence on capital structure.

But agency theory interprets this relationship by a decrease in the agency's debt cost to these companies, which encourages them to borrow more. Nenu et al. (2018) found a positive relationship between the proportions of tangible assets and loan financing. The study by Rodrigues et al. (2017) indicates that a company which owns large assets gets a low interest rate because these loans are secured by the value of tangible assets. From here, it is expected that the availability of tangible assets in the structure of the company's will positively affect the extent to which Jordanian companies use debt, and thus the following hypothesis can be formulated. The first hypothesis: There is a positive relationship between the availability of tangible assets at a company and the extent to which the company uses debt financing.

\subsection{Profitability}

Accounting literature has stated that companies seek to achieve profit. Profitability is a primary objective for any business, essential for its survival and continuity, and it is a major goal for investors, It also reflects management efficiency in using available resources and assets in its possession. In addition, it is considered an important indicator of business success from the creditors' viewpoint, which moves the actual financing structure away from the ideal structure. So, differentiation theory assumes that the company with the highest profits will resort to borrowing more to return the financing structure to the assumed ideal situation, On the other hand, pecking order theory explains the 
relationship between profitability and borrowing differently, as internal financing is always preferred by the company because there is no cost of information asymmetry. Therefore, the most profitable companies will reduce financing by borrowing. Strýčková (2015) found an inverse (negative) relationship between profitability and debt, which is consistent with pecking order theory, Whereas higher profitability companies are less inclined to use financing by loans (Aggarwal \& Padhan, (2017), so management uses retained earnings rather than accumulating debt, where high debt restricts management through repayment programs, while retained earnings do not cost the company with issuance costs, and they do not have the cost of information asymmetry, as found by Sakr \& Bedeir (2018), Profitable companies prefer to rely on retained earnings to finance their investments rather than the debt financing method, but in the event that company exhausts internal sources of funding, the company may use external sources of financing. According to that, there is a negative relationship between profitability and financing by loans in the Jordanian companies listed, and based on this, the following hypothesis can be formulated. The second hypothesis: There is an inverse relationship between the company's profitability and the extent of the company's resorting to debt financing.

\subsection{Company Size}

Practical studies have found company size affects its borrowing ability, as the expansion of borrowing is associated with a positive relationship with company size, (Strýčková, 2015; Aggarwal \& Padhan,2017; Chakrabarti \& Chakrabarti, 2019). The larger sized company has a greater ability to borrow. The reason may be that the large company often enjoys the trust of financiers more than small companies are trusted. Also, the large company has the ability and confidence to pay off its debts (Titman \& Wessels, 1988; El Bahsh et al., 2018). Information asymmetry theory suggests that investors do not have sufficient information about the company, but the effect is less for large companies, and the reason may be due to the inclination of the large-sized company to provide more information to investors compared to small companies. Therefore, asymmetry of information with investors is less in large companies, and the large company has the ability to diversify its investments to reduce the risks (Titman \& Wessels, 1988). Strýcková (2015) stated that the size of the company has a positive impact on its ability to finance loans, based on the above. It is expected that the relationship will be positive between the size of the company and loan financing in the listed Jordanian companies, and the following hypothesis will be tested. The third hypothesis: There is a positive relationship between the size of the company and the extent of the company's use of debt financing.

\subsection{Growth Opportunities}

Titman \& Wessels (1988) defined growth opportunities as capital assets that add value to the company but cannot be used as collateral for loans and do not result in any current income. Myers (1984) linked the relationship between growth opportunities and borrowing ratios that the agency's problem represented through loans. Since companies that have growth opportunities seek to avoid this problem, it is expected that their investments will be funded by ownership, which means that the expected relationship between borrowing and growth opportunities will be negative. Therefore, the following hypothesis can be formulated. The fourth hypothesis: There is a negative relationship between the growth opportunities available to company and the extent of company's dependence on debt financing.

\subsection{Effective Tax Rate}

Loan interest is an expense that is deducted from revenue before tax, which results in tax savings, having a positive impact on the value of the company (Modigliani \& Miller, 1963). Given the direct relationship between the tax rate and tax savings, meaning the higher actual tax rate on profits, the higher the tax savings for company, the greater the motivation for companies to rely more on borrowed funds. Huang \& Song (2006) argued that taxes should affect the capital structure, that a company with high actual taxes uses debt more to obtain tax savings, and that the reason why many previous studies have failed to find clear tax implications for financing decisions is implied by the theory of Miller \& Modigliani. This result from the fact that the debt ratio is the result of the accumulation of financing decisions year after year, but the effect of the tax will appear on the annual change in borrowing and not on the borrowing balance. So, the desire to increase debt financing for each year alone will be affected positively with an increase actual tax rate. This is consistent with the theory of Miller \& Modigliani, but Huang \& Song (2006) failed to prove this assumption. MacKie-Mason (1990) noted that everyone believes that taxes must affect the funding decision, but few studies have found evidence in practice for such relationship. This study will proceed on the same previous basis and assume that an increase in the actual tax rate is expected to lead to an increase in the tendency toward borrowing due to the tax savings achieved by the company that uses loan financing. Thus, the following hypothesis can be formulated. The fifth hypothesis: There is a positive relationship between the actual tax rate and the extent of the company's resorting to borrowing financing 


\subsection{Tax Debt-Non Shields}

Reduced tax items other than interest, such as depreciation, amortization and provisions, affect profits. If such expenses are higher, then this leads to less profit and, therefore, less taxes paid and increased net cash flow. This is a similar effect to tax savings from borrowing, so the company's need to borrow reduces if the company has other tax-reducing items such as consumption. So, a negative relationship is expected between the volume of tax-deductible items and the company's borrowing ratio (DeAngelo \& Masulis, 1980). The amount of debt is negatively affected by the existence of tax-deductible items, such as consumption or investment exemption, as they are alternatives to the tax benefits of debt financing (Huang \& Song, 2006). IIt is expected that the relationship is negative between tax-deductible items (other than interest) and loan financing in the listed Jordanian public shareholding companies. Thus, the following hypothesis can be formulated. Sixth hypothesis: There is a negative relationship between the size of tax-deductible items other than interest in the company and the tendency of the company to use loans. Table 1 shows the expected relationship of the factors specified for the study according to theories of the financing structure.

Table 1. The expected relationship between the factors determining the capital structure and the degree to which the company uses debts according to theories of the financing structure

\begin{tabular}{lll}
\hline Variable & Expected theoretical relationship & Theory \\
\hline Company size & Positive relationship & Differentiation theory \\
\hline Tangible asset & Positive relationship & Tangible assets \\
\hline Profitability & Negative relationship & Differentiation theory (order) \\
\hline Growth & Negative relationship & Agency theory \\
\hline Discounted items & Negative relationship & The theory of differentiation of taxes, excluding interest \\
\hline Effective tax rate & Positive relationship & Differential theory \\
\hline
\end{tabular}

\section{Study Methodology}

The study population consists of all the Jordanian public shareholding companies listed in Amman Stock Exchange (ASE) during the period 2014 to the year 2018. All the financial companies represented the banking sector and insurance companies were excluded from the study population because the financing decision in these companies is restricted by legislative restrictions different from the rest of companies (Cho et al., 2014). So, the study sample involves all the non-financial listed companies, provided that their annual data are available, as the data were collected manually from the financial statements of the companies, whether published on the ASE website or by referring directly to the company's annual printed reports that could not be obtained from its data from the ASE website. The study sample consists of 96 companies listed on the ASE. The total number of analyses was 480 observations (company-year). Some researchers mention that the sample size may have an effect on the accuracy of results (Booth et al., 2001) so the number of observations applied will enable us to overcome such problems. From other hand Li, L., \& Islam, S. Z. (2019) detect that some factors related industry - are important in constitute capital structure.

\subsection{Variables and Study Model}

To discover the determinants of the financing structure, an explanatory study in Jordan is carried out. Standard models were used to explain the reasons for the difference between companies in the degree of their use of loans. The following is a discussion for the study variables, both dependent and independent.

\subsubsection{Dependent Variable}

The dependent variable in this study is the (borrowing) debt ratio. It is measured according to the previous literature in several ways, including: book value of assets, or the borrowing debt-to-assets ratio at market value, the market value method has the advantage in that it is closer to reality and reflects the risks of bankruptcy more accurately, while book values reflect the effect of accumulating previous financing operations over time. This study will use both methods to measure the dependent variable, similar to many previous studies, such as (Fama \& French 2002; Loof, 2004; Rajan \& Zingales, 1995; Welch, 2004; El Bahsh et al., 2018; D'Mello,et al., 2018). The (borrowing) debt-to-assets ratio at book value is a ratio that results from dividing the total loans by the total assets with book 
value. Increasing the debt-to-assets ratio means that the company relies on higher ratios than the financial leverage.

The ratio of (borrowing) debt to assets at market value is measured as the ratio of total loans (debts) to assets at market value. Assets are calculated at market value through the following equation: total assets - equity rights at book value + market value of equity rights. The market value of equity rights is measured by multiplying the number of shares by the market value per share. The aforementioned calculation method assumes that the book value and the market value of debts are equal. This assumption makes more sense in Jordan because debts in all Jordanian regions are bank debts (loans) that have no market value, and therefore the only adjustment to access the market value will be in property rights. States that loan do not include commercial debt financing.

The (borrowing) debt-to-assets ratio at book value is calculated as follows: total loans / total assets. The borrowing-to-assets ratio at market value is calculated as follows: total loans / (total assets - equity at book value + equity at market value).

\subsubsection{Independent Variables}

This study included six independent variables selected from previous studies (DeAngelo \& Masulis, 1980; Rajan \& Zingales, 1995; Booth et al., 2001; Fama \& French, 2002; Welch, 2004; Huang \& Song, 2006; El Bahsh et al., 2018).

Table 2. Measurement of independent variables

\begin{tabular}{|c|c|c|}
\hline Variable & Code & Measurement method \\
\hline Tangible assets & TANG & Tangible long-term assets / Total assets \\
\hline Company size & SIZE & Logarithm (sales) \\
\hline Profitability & PROFIT & (Operating income + depreciation / total assets) \\
\hline Growth & GROWTH & $\begin{array}{l}\text { Market value at book value }=(\text { Total assets }- \text { equity at book } \\
\text { value }+ \text { equity at market value } / \text { total assets at book value })\end{array}$ \\
\hline $\begin{array}{l}\text { Items deceased tax effective } \\
\text { interest rested }\end{array}$ & TAX & Non-cash expenses / total assets \\
\hline Effective tax rate & ETAX & Provision for tax / operating income \\
\hline
\end{tabular}

Tangible assets were measured as follows. Through the ratio of long-term tangible assets to the total assets in the company, the increase in the ratio of tangible assets to total assets is an indication of company's ability to use these assets as collateral for loans. So, it is expected that the relationship will be positive between the ratio of tangible assets and the borrowing ratio.

Company size could be measured by number of employees or through the sales logarithm. The current study uses the logarithm of sales to measure size. The size of the company is expected to have a positive impact on borrowing rates.

Profitability is measured by dividing the operating income before interest and tax on total assets. It is expected, according to pecking order theory, that the relationship will be negative with borrowing ratios.

The growth was measured by the company market value to company book value (Rajan and Zingales, 1995). The ratio of the market value to the book value gives information about the mix of assets that the company owns. The tax variables were added to the previous model to test the direction of their effect (Antoniou et al., 2002).

Table 2 presents the parameters of independent variables in this study. The relationship between dependent and independent variables was modeled with a multiple linear model as follows:

$$
\text { leve }=\alpha 0+\alpha 1 \text { tang }+\alpha 2 \text { size }+\alpha 3 \text { profit }+\alpha 4 \text { growth }+\alpha 5 \operatorname{tax}+\alpha 6 \text { Etax }+\mathrm{e} .
$$

\subsubsection{Standard Estimation Methods}

The study model was estimated using regression models for two-dimensions. This is known as panel regression. It combines cross-sectional and time series at the same time. This method allows the use of the largest amount of data with the ability to control the effect of common factors between different companies at the same time and period, as well as the common factors of the same company over time, through a mechanism similar to the effect of adding imaginary variables to the model to isolate the effect of common factors between companies or between the years. This is called the fixed effect model. As well, it is possible to use a random effect model. The random effect model is 
a method that allows greater degrees of freedom in the model compared to the fixed effect, and it may be more efficient in estimating in some cases. The choice between not using any effect (regression pooled) or using the fixed effect or using the random effect depends statistical tests (Baltagi, 2008; Greene, 2003).

The choice between fixed effect or not using any effect depends on testing the null hypothesis. The fixed variable in the model for all cross-sectional or time series is fixed and equal. Thus, there is no need to apply a fixed effect. So, this hypothesis is tested by using the F-test. The test between the fixed effect model and the random effect model is based on a test called the Hausman test. It is preferable to test the null hypothesis using random effect model. The current study applied a test including four models to choose the most efficient model and more suitable model related with Jordanian companies listed in the ASE over the years that extend from the year 2014 to the year 2018.

\section{Results and Discussion}

\subsection{Sample Description Characteristics}

Table 3 presents the most important descriptive indicators of the study variables that will be used in estimating the models, including: the arithmetic mean, the median, the standard deviation, the lower and upper value, and the number of observations. We notice that the average borrowing rate in Jordanian companies is low with an average of $8 \%$ at book value and $9 \%$ at market value. This does not mean that companies do not use the money of others, but they use commercial financing more than borrowing. It is also noted that the ratio of the market value to the book value is less than one, which means that there is a decrease in the market price from the minimum fair price.

Table 3. Descriptive indicators of the study variables

\begin{tabular}{|c|c|c|c|c|c|c|}
\hline Variable & Mean & Median & $\begin{array}{l}\text { Maximum } \\
\text { value }\end{array}$ & $\begin{array}{l}\text { Minimum } \\
\text { value }\end{array}$ & $\begin{array}{l}\text { Standard } \\
\text { deviation }\end{array}$ & $\begin{array}{l}\text { Number of } \\
\text { observations }\end{array}$ \\
\hline Borrowing ratios to book value & 0.083 & 0.018 & 0.712 & 0.0000 & 0.108 & 480 \\
\hline $\begin{array}{l}\text { Borrowing ratios to market } \\
\text { value }\end{array}$ & 0.095 & .024 & 1.786 & 0.0000 & 0.165 & 480 \\
\hline Company size (sales algorithm) & 3.56 & 2.36 & 4.543 & 1.308 & 0.965 & 479 \\
\hline Tangible assets & 0.675 & 0.954 & 0.653 & 0.034 & 0.324 & 480 \\
\hline Profitability & 0.077 & 0.062 & 0.833 & -1.022 & 0.156 & 480 \\
\hline Market value / book value & 0.891 & 0.675 & 4.227 & 0.008 & 0.231 & 480 \\
\hline $\begin{array}{l}\text { Tax-deductible items except } \\
\text { interest }\end{array}$ & 0.076 & 0.018 & 0.562 & 0.000 & 0.087 & 479 \\
\hline Actual tax rate & 0.063 & 0.034 & 1.874 & 0.000 & 0.401 & 478 \\
\hline
\end{tabular}

\subsection{Correlation Analysis}

Table 4 presents correlation analysis between the study variables, where the strength of the relationship and its direction appears between the independent variables and the dependent variable. The pairwise relationships among the independent variables may indicate a problem of interconnection in the regression analysis. By looking at Table 4, we note there is no interconnection problem. Some scholars indicate that the interconnection problem occurs if the correlation coefficient between independent variables is large (0.7 up to 0.9) (Asteriou \& Hall, 2007). The largest correlation coefficient between the independent variables in the table does not exceed 0.4 . This assures that there is no interconnection problem. 
Table 4. Correlation matrix between study variables

\begin{tabular}{|c|c|c|c|c|c|c|c|c|}
\hline & $\begin{array}{l}\text { Borrowing } \\
\text { ratios to } \\
\text { book value }\end{array}$ & $\begin{array}{l}\text { Borrowing } \\
\text { ratios to } \\
\text { book value }\end{array}$ & $\begin{array}{l}\text { Volum } \\
\mathrm{e}\end{array}$ & $\begin{array}{l}\text { Tangibl } \\
\text { e assets }\end{array}$ & $\begin{array}{l}\text { Profita } \\
\text { bility }\end{array}$ & $\begin{array}{l}\text { Market } \\
\text { value / } \\
\text { book } \\
\text { value }\end{array}$ & $\begin{array}{l}\text { Tax-deducti } \\
\text { ble items } \\
\text { except } \\
\text { interest }\end{array}$ & $\begin{array}{l}\text { Actual } \\
\text { tax rate }\end{array}$ \\
\hline $\begin{array}{l}\text { Borrowing ratios } \\
\text { to book value }\end{array}$ & 1.000 & & & & & & & \\
\hline $\begin{array}{l}\text { Borrowing ratios } \\
\text { to book value }\end{array}$ & 0.075 & 1.000 & & & & & & \\
\hline Volume & 0.132 & 0.171 & 1.000 & & & & & \\
\hline Tangible assets & 0.278 & 0.117 & -0.066 & 1.000 & & & & \\
\hline Profitability & -0.256 & -0.445 & 0.3532 & -0.121 & 1.000 & & & \\
\hline $\begin{array}{l}\text { Market value / } \\
\text { book value }\end{array}$ & 0.073 & -0.128 & 0.208 & -0.071 & 0.111 & 1.000 & & \\
\hline $\begin{array}{l}\text { Tax-deductible } \\
\text { items except } \\
\text { interest }\end{array}$ & -0.033 & -0.141 & -0.221 & -0.052 & 0.120 & -0.069 & 1.000 & \\
\hline Actual tax rate & -0.051 & -0.019 & -0.023 & 0.041 & 0.025 & -0.158 & -0.046 & 1.000 \\
\hline
\end{tabular}

\subsection{Estimate Study Models}

The regression models for the dependent variable, which is the borrowing ratio for the assets at the book value, and the borrowing ratios for assets at market value are estimated separately in Table 5 using the independent variables mostly applied in the literature, namely company size, tangible assets, profitability and market value to the book value (to quantify growth opportunities). Tax-related variables were not included in these two tables (Tables 5 and 6). The models were estimated using four methods: non-use of impact (Model 1), cross-sectional effect (Model 2), two-way fixed effect, cross-section and time (Model 3), and random effect (Model 4). Tests were performed to discover the appropriate model by applying the F-test and the Hausman test. It was found that the random effect model is the most suitable for this (Jordanian) data. All models are presented in Table 5 in order to compare the results and understand the suitability.

Table 5. Basic determinants of the financing decision using the book value of the borrowing ratio, as a dependent variable

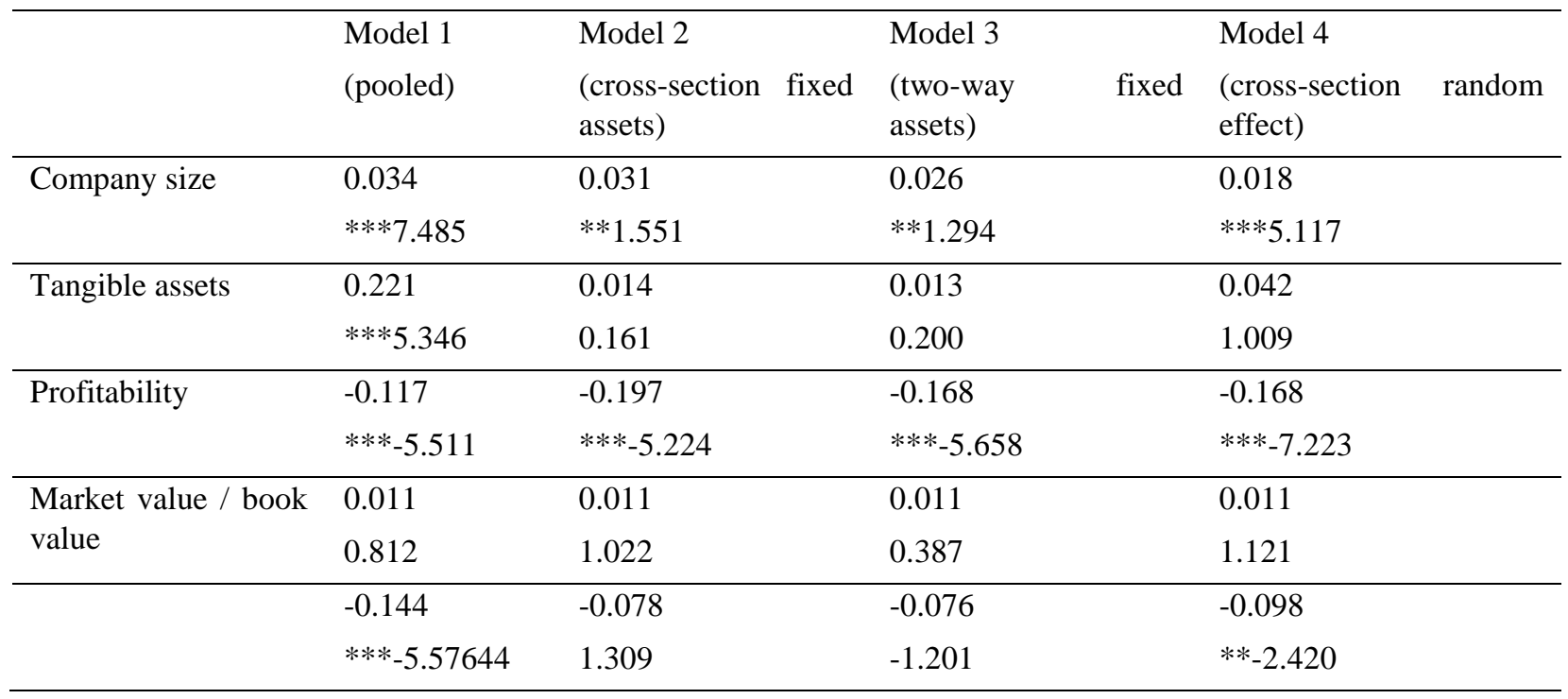




\begin{tabular}{lllll}
\hline R-squared & 0.241 & 0.811 & 0.873 & 0.311 \\
\hline Adjusted R-squared & 0.258 & 0.711 & 0.734 & 0.278 \\
\hline $\begin{array}{l}\text { Durbin-Watson } \\
\text { statistic }\end{array}$ & 0.824 & 1.225 & 1.478 & 1.454 \\
\hline F-statistic & $* * * 27.462$ & $* * * 18.533$ & $* * * 15.113$ & 19.122 \\
\hline Prob(F-statistic) & & & 0.000 & 0.000 \\
\hline Observation N & 480 & 480 & 480 & 480 \\
\hline
\end{tabular}

Models 1, $2 \& 3$ use cross-section weights (PCSE), standard errors \& covariance (d.f. corrected)

Model 4 uses Swamy and Arora estimator of component variances

The results of regression analysis are shown in Table 6. There are two variables showing high stability in all models, and both dependent variables, as determinants of the borrowing ratio, are company size and profitability. The effect of company size was direct, which is consistent with differentiation theory and pecking order theory. Also, profitability has a negative impact, as predicted by pecking order theory. These results are similar to many previous studies in developed and developing countries (Booth et al., 2001; Huang \& Song, 2006; Rajan and Zingales, 1995; Strýčková, 2015; El Bahsh et al., 2018). Regarding tangible assets, their effect was positive and strong when no effect was used, whether with borrowing ratio in the book value or market value. This is the expected result under the theory of differentiation, but the effect of this factor has lost its statistical strength with both variables. Once you enter the fixed effect or random effect of the model, finally the market value to the book value of the company, it showed a different behavior between the two dependent variables. There was no significant relationship for the relationship when using the book value of the debt ratio. The relationship was positive and strong when using the market value. This is the opposite of the expected negative relationship, but it corresponds to the expectations of the pecking order theory since growth means a need for new financing. According pecking order theory, the source of this funding will be debt once they exceed the amount of financing needed for the amount of retained earnings. So, the assumption is that the stability profitability of the company's debt ratio will be higher for companies with higher growth opportunities.

Table 6. The basic determinants of the financing decision, using the market value of the borrowing ratio, as a dependent variable

\begin{tabular}{|c|c|c|c|c|}
\hline & Model 1 & Model 2 & Model 3 & Model 4 \\
\hline \multirow[t]{2}{*}{ Company size } & 0.034 & 0.022 & 0.015 & 0.044 \\
\hline & $* * * 5.564$ & 0.581 & 0.371 & $* * * 3.338$ \\
\hline \multirow{2}{*}{ Tangible assets } & 0.980 & -0.131 & -0.033 & 0.018 \\
\hline & $* * * 2.153$ & -0.811 & -1.077 & -0.128 \\
\hline \multirow[t]{2}{*}{ Profitability } & -0.391 & -0.389 & -0.311 & -0.503 \\
\hline & $* * *-3.477$ & $* * *-3889$ & $* * *-3.882$ & $* * *-10.415$ \\
\hline \multirow{4}{*}{$\begin{array}{l}\text { Market value / book } \\
\text { value }\end{array}$} & -0.041 & 0.048 & -0.051 & -0.053 \\
\hline & $* * *-3.008$ & $* * *-5.013$ & $* * *-4.441$ & $* * *-2.266$ \\
\hline & -0.152 & 0.163 & 0.067 & 0.013 \\
\hline & $* * *-4.311$ & 0.745 & 0.889 & 0.201 \\
\hline R-squared & 0.401 & 0.771 & 0.687 & 0.378 \\
\hline Adjusted R-squared & 0.388 & 0.717 & 0.627 & 0.369 \\
\hline Durbin-Watson statistic & 1.109 & 1.712 & 1.881 & 1.764 \\
\hline F-statistic & $* * * 33.228$ & $* * * 18.787$ & $* * * 22.443$ & $* * * 35.412$ \\
\hline \multicolumn{5}{|c|}{ Model 1, $2 \& 3$ use cross-section weights (PCSE), standard errors \& covariance (d.f. corrected) } \\
\hline \multicolumn{5}{|c|}{ Model 4 uses Swamy and Arora estimator of component variances } \\
\hline \multicolumn{5}{|c|}{$*, * *, * * *$ mean significantly less than $1 \%, 5 \%$, and $10 \%$, respectively } \\
\hline
\end{tabular}


After testing the basic study variables, the impact of tax on borrowing rate will be tested. The test introduces two variables that reflect the effect of the tax on the study model that was estimated using the random effect, an estimate that was previously defined to be the most appropriate for the data under study. Two variables that have relationship with tax will be entered: the items that reduce profitability other than interest, and the actual tax rate on the two models separately. Table 7 shows the results of estimating these models. Fixed assets can be provided as collateral, and thus loans can be obtained at a lower cost (the hypothesis of secured loans). So, companies borrow more whenever they have more tax-deductible items, which is an explanation consistent with the differentiation theory. But the actual tax rate did not have a statistically significant impact on the borrowing rate, and this result is consistent with previous studies (Huang \& Song, 2006; Amraoui et al., 2018).

The results above are summarized in Table 7 , which displays the relationship that was anticipated and the relationship that was found from the data, as well as the theory that explains the actual relationship. We note that factors and relationships are compatible with arrangement theory. It had the largest share of the interpretation. This is expected in light of the large asymmetry of information that makes Jordanian companies dependent on internal financing and financing through bank borrowing. Issuing new bonds or stocks is very expensive in this environment, due to the high costs of reverse selection, which makes companies refrain from it, so there is no bond market in Jordan.

Table 7. The effect of introducing tax-related variables on the model

\begin{tabular}{|c|c|c|c|c|}
\hline & Model 1 & Model 2 & Model 3 & Model 4 \\
\hline \multirow[t]{2}{*}{ Company size } & 0.056 & 0.041 & 0.034 & 0.036 \\
\hline & $* * * 5.561$ & $* * * 3.436$ & $* * * 4.561$ & $* * * 3.338$ \\
\hline \multirow[t]{2}{*}{ Tangible assets } & 0.980 & -0.131 & -0.033 & 0.018 \\
\hline & -0.468 & -0.674 & -1.134 & -0.244 \\
\hline \multirow[t]{2}{*}{ Profitability } & -0.391 & -0.389 & -0.311 & -0.503 \\
\hline & $* * *-3.477$ & $* * *-3889$ & $* * *-8.344$ & $* * *-10.415$ \\
\hline \multirow{2}{*}{$\begin{array}{l}\text { Market value / book } \\
\text { value }\end{array}$} & -0.038 & 0.037 & -0.018 & -0.032 \\
\hline & $* * *-14.008$ & $* * *-7.013$ & $* * *-12.441$ & $* * *-9.266$ \\
\hline \multirow{2}{*}{$\begin{array}{l}\text { Profit-reduced } \\
\text { without interest }\end{array}$} & 0.268 & 0.268 & - & - \\
\hline & $* * * 6.232$ & $* * * 8.232$ & - & - \\
\hline \multirow[t]{4}{*}{ Actual tax rate } & - & - & 0.024 & 0.008 \\
\hline & - & - & 0.208 & -0.544 \\
\hline & -0.152 & 0.163 & 0.067 & 0.013 \\
\hline & $* * *-4.311$ & 0.745 & 0.889 & 0.201 \\
\hline R-squared & 0.412 & 0.672 & 0.342 & 0.224 \\
\hline Adjusted R-squared & 0.408 & 0.644 & 0.326 & 0.212 \\
\hline Durbin-Watson statistic & 1.481 & 1.672 & 1.783 & 1.659 \\
\hline F-statistic & $* * * 28.258$ & $* * * 47.287$ & $* * * 31.483$ & $* * * 28.567$ \\
\hline
\end{tabular}

Method :Panel EGLS (Cross-section random effects)

Swamy and Arora estimator of component variances

$*, * *, * * *$ mean significantly less than $1 \%, 5 \%$, and $10 \%$, respectively

\section{Conclusions}

Depending on capital structure, companies should choose between one of two strategies for constitute its capital structure, (when need more fund) first: through issued new stocks (common \& preference shares ) or issued new debts (bonds), this selection depending on different variables as mentioned in accounting and finance literature, that 
discussed in details previously.

The factors that affect the financing structure of Jordanian companies are generally similar to the factors found in many economies in developing countries, so this study has found that the company size, growth opportunities, profitability and tax-deductible items are the most important determinants of the financing structure. The relationship of growth opportunities, the tax-deductible items with the financing structure are positive, contrary to what was expected, which gives the impression that the factors associated with pecking order theory were stronger than what is usually found in other countries, this is an indication of the depth of the problem of information asymmetry in the Jordanian market, the reason for such result may be that Jordanian investors distrust data presented by companies, or the ownership structure is controlled by limited category, which is not available to the rest of shareholders to participate in decision making. So, these investors are reluctant to invest in securities except after a significant discount on their fair value. It seems that companies are aware of this problem.

Also companies depend on debt once they exceed the amount of financing needed for the amount of retained earnings. So, the stability profitability of the company's debt ratio will be higher for companies with higher growth opportunities. Furthermore, companies borrow more whenever they have more tax-deductible items or more tangible assets, which is an explanation consistent with the differentiation theory. So, Jordanian companies do not try to offer securities to the public to obtain financing after the initial issuance, but prefer to rely on self-financing and then depend on bank financing. In limited cases, companies issue private shares, and companies rarely resort to public issuance to obtain financing except for the initial issue.

This result requires that Jordanian companies first and the market regulators secondly be concerned with creating trust for investors by providing the data that serve investors in decision-making consistent with (kanakriyah, 2017). This requires developing the accounting profession and adopting clear accounting standards. This is only what will open the door in the future to an active market for bonds and stocks serving companies, not just finance speculation that does not serve the economy but rather harms it. This study opens the door for future studies on the impact of the asymmetry of information in funding decisions and in the area of policies to be taken to minimize the impact of the problems of information asymmetry in the Jordanian financial market

the findings indicate that the companies prefer to use commercial financing more than borrowing from other methods such as( bonds), this result could be attributed because Jordanian investment market is not familiar with investment through ( bonds) or because they do not trust companies managements or because have different Investment culture

The results detected how to constitute the suitable financial structure and how making a balance between sources of finance, (company size, growth opportunities, profitability and tax-deductible) items are the most important determinants of the financing structure. Also revealed the weakens role of companies managers and Amman Stock Exchange of (Amman Stock exchange) regulators, which require to focusing efforts to improving information deloused to users.

Current study suffers from some specific limitations, limited number researches which have been discuss this issue. Therefore, this study extensively contributes to the shortage literature on the perceived the main factors that may effect on financial structure especially in developing countries. one of important research limitations availability of financial information plus difficulty accessing information in developing countries such as Jordan. Another weakness point relating to its methodology, because this study used a quantitative analysis based on the data published in financial statements. It would be more beneficial if used qualitative analysis in addition to quantitative analysis to applying (triangulation method) to assure and enhance its result, also we can improve the model interpretation by taking more relevant variables. Through looking for future studies, we recommend more studies to understand the role of asset ownership and its programs for expansion and its effects on company value.

\section{References}

Aggarwal, D., \& Padhan, P. C. (2017). Impact of capital structure on firm value: evidence from Indian Hospitality Industry. Theoretical Economics Letters, 7(4), 982-1000. https://doi.org/10.4236/tel.2017.74067

Amraoui, M., Jianmu, Y., \& Bouarara, K. (2018). Firm's capital structure determinants and financing choice by industry in Morocco. International Journal of Management Science and Business Administration, 4(3), 41-51. https://doi.org/10.18775/ijmsba.1849-5664-5419.2014.43.1005

Antoniou, A., Guney, Y., \& Paudyal, K. (2002). Determinants of corporate capital structure: Evidence from European countries. Working paper, University of Durham. https://doi.org/10.2139/ssrn.302833

Asteriou, D., \& Hall, S. G. (2007). Applied Econometrics: A Modern Approach Using Eviews and Microfit (Revised 
Edition). Palgrave Macmillan.

Baltagi, B. (2008). Econometric Analysis of Panel Data. John Wiley \& Sons.

Booth, L., Aivazian, V., Demirguc-Kunt, A., \& Maksimovic, V. (2001). Capital structures in developing countries. The Journal of Finance, 56(1), 87-130. https://doi.org/10.1111/0022-1082.00320

Butzbach, O., \& Sarno, D. (2019). To what extent do regional effects influence firms' capital structure? The case of southern Italian SMEs'. International Journal of Financial Studies, 7(1), 3. https://doi.org/10.3390/ijfs7010003

Chakrabarti, A., \& Chakrabarti, A. (2019). The capital structure puzzle-Evidence from Indian energy sector. International Journal of Energy Sector Management. https://doi.org/10.1108/IJESM-03-2018-0001

Cho, S. S., El Ghoul, S., Guedhami, O., \& Suh, J. (2014). Creditor rights and capital structure: Evidence from international data. Journal of Corporate Finance, 25, 40-60. https://doi.org/10.1016/j.jcorpfin.2013.10.007

DeAngelo, H., \& Masulis, R. W. (1980). Optimal capital structure under corporate and personal taxation. Journal of Financial Economics, 8(1), 3-29. https://doi.org/10.1016/0304-405X(80)90019-7

D'Mello, R., Gruskin, M., \& Kulchania, M. (2018). Shareholders valuation of long-term debt and decline in firms' leverage ratio. Journal of Corporate Finance, 48, 352-374. https://doi.org/10.1016/j.jcorpfin.2017.11.006

El Bahsh, R., Alattar, A., \& Yusuf, A. N. (2018). Firm, industry and country level determinants of capital structure: Evidence from Jordan. International Journal of Economics and Financial Issues, 8(2), 175-190.

Fama, E. F., \& French, K. R. (2002). Testing trade-off and pecking order predictions about dividends and debt. The Review of Financial Studies, 15(1), 1-33. https://doi.org/10.1093/rfs/15.1.1

Ghose, B., \& Kabra, K. C. (2019). Capital Structure Dynamics and Financing Imbalance: Evidence from an Emerging Economy. Emerging Economy Studies, 5(2), 103-124. https://doi.org/10.1177/2394901519870766

Greene, W. H. (2002). Econometric Analysis (5th ed.). Pearson.

Huang, G., \& Song, F. M. (2006). The determinants of capital structure: Evidence from China. China Economic Review, 17(1), 14-36. https://doi.org/10.1016/j.chieco.2005.02.007

Jensen, M. C., \& Meckling, W. H. (1976). Theory of the firm: Managerial behavior, agency costs and ownership structure. Journal of Financial Economics, 3(4), 305-360. https://doi.org/10.1016/0304-405X(76)90026-X

Kanakriyah, R. (2017). The impact of accounting information systems on the banks success: Evidence from Jordan. Research Journal of Finance and Accounting, 8, 17.

Kraus, A., \& Litzenberger, R. H. (1973). A state preference model of optimal financial leverage. The Journal of Finance, 28(4), 911-922. https://doi.org/10.1111/j.1540-6261.1973.tb01415.x

Li, L., \& Islam, S. Z. (2019). Firm and industry specific determinants of capital structure: Evidence from the Australian market. International Review of Economics \& Finance, 59, 425-437. https://doi.org/10.1016/j.iref.2018.10.007

Loof, H. (2004). Dynamic optimal capital structure and technical change. Structural Change and Economic Dynamics, 15(4), 449-468. https://doi.org/10.1016/j.strueco.2003.05.001

MacKie-Mason, J. K. (1990). Do taxes affect corporate financing decisions?. The Journal of Finance, 45(5), 1471-1493. https://doi.org/10.1111/j.1540-6261.1990.tb03724.x

Mekha, P. G., Lakshmi, S. M., \& Suresha, B. (2019). Determinants of Capital Structure-An Evidence from Indian BFSI Sector. Asian Journal of Management, 10(2), 115-118. https://doi.org/10.5958/2321-5763.2019.00019.2

Modigliani, F., \& Miller, M. H. (1958). The cost of capital, corporation finance and the theory of investment. The American Economic Review, 48(3), 261-297.

Myers, S. C. (1984). The capital structure puzzle. The Journal of Finance, 39(3), 575-592. https://doi.org/10.2307/2327916

Myers, S. C., \& Majluf, N. S. (1984). Corporate financing and investment decisions when firms have information that investors do not have. Journal of Financial Economics, 13, 187-221. https://doi.org/10.1016/0304-405X(84)90023-0

Nenu, E., Vintilă, G., \& Gherghina, Ş. (2018). The impact of capital structure on risk and firm performance: Empirical evidence for the Bucharest stock exchange listed companies. International Journal of Financial 
Studies, 6(2), 41. https://doi.org/10.3390/ijfs6020041

Rajan, R. G., \& Zingales, L. (1995). What do we know about capital structure? Some evidence from international data. The Journal of Finance, 50(5), 1421-1460. https://doi.org/10.1111/j.1540-6261.1995.tb05184.x

Rajverma, A. K., Arrawatia, R., Misra, A. K., \& Chandra, A. (2019). Ownership structure influencing the joint determination of dividend, leverage, and cost of capital. Cogent Economics \& Finance, 7(1), 1600462. https://doi.org/10.1080/23322039.2019.1600462

Rodrigues, S. V., Moura, H. J. D., Santos, D. F. L., \& Sobreiro, V. A. (2017). Capital structure management differences in Latin American and US firms after 2008 crisis. Journal of Economics, Finance and Administrative Science, 22(42), 51-74. https://doi.org/10.1108/JEFAS-01-2017-0008

Sakr, A., \& Bedeir, A. (2018). Industry level and country level determinants of capital structure: Evidence from Egypt. International Research Journal of Finance and Economics, 170, 132-151.

Shil, N., Hossain, M. N., \& Ullah, M. N. (2019). Exploring the underlying factors affecting capital structure decision: A quantitative analysis. Journal of Corporate Accounting \& Finance, 30(4), 69-84. https://doi.org/10.1002/jcaf.22404

Shukla, S. (2019). A Study of Leverage Analysis and Srofitability for Dr. Reddy's Laboratories. Journal of Bank Management \& Financial Strategies, 2(3), 7-14.

Strýčková, L. (2015). Factors determining the corporate capital structure in the Czech Republic from the perspective of business entities. Ekonomika A Management, 18(2), 40-56. https://doi.org/10.15240/tul/001/2015-2-004

Titman, S., \& Wessels, R. (1988). The determinants of capital structure choice. The Journal of Finance, 43(1), 1-19. https://doi.org/10.1111/j.1540-6261.1988.tb02585.x

Welch, I. (2004). Capital structure and stock returns. Journal of Political Economy, 112(1), 106-131. https://doi.org/10.1086/379933 